\title{
PENERAPAN DISIPLIN POSITIF DALAM PEMBELAJARAN JARAK JAUH DI SMP NEGERI 1 BANYUMAS
}

\author{
Mistina Hidayati' ${ }^{1}$ Abdul Wahid Bambang Suharto ${ }^{2}$ \\ 1,2 Institut Agama Islam Negeri (IAIN) Purwokerto \\ e-mail: tina.banyumas@gmail.com
}

\begin{abstract}
The issue with distance learning in social studies subjects at SMP Negeri 1 Banyumas is students' lack of discipline in responding to and completing assignments assigned by the teacher. According to observations made during the first three months of the odd semester of 2020/2021, the average student attendance rate in distance learning is $75 \%$. Meanwhile, students have an average of $70 \%$ discipline when it comes to collecting assignments or responding to the teacher. It is possible because the teacher has not instilled positive discipline in the students, resulting in subpar results. The goal of this research is to describe an overview of positive discipline implementation in the classroom, including the preparation of class agreements, implementation, and results. The findings revealed that implementing positive discipline through class agreement had a positive impact on both teachers and students. The student discipline level in the assignment is $86 \%$, and the average attendance is $90 \%$; the qualifications are excellent. The results of interviews with students conducted via Google Forms and distributed by the teacher regarding the use of positive discipline received a very positive response, with 96.73 percent responding positively. As a result, teachers should use positive discipline during distance learning. This clearly demonstrates that, even when learning is done at a distance, critical assessment of learning can still be conducted.
\end{abstract}

Keywords: positive discipline, distance learning, social sciences

Received: 06 Februari 2021

Accepted: 03 Juni 2021

Published: 28 Juni 2021

\section{PENDAHULUAN}

Pandemi virus corona (Covid 19) pada awal tahun 2020, merubah segala aspek kehidupan masyarakat, tak terkecuali bidang pendidikan. Keputusan pemerintah yang mendadak memindahkan proses pembelajaran dari sekolah menjadi di rumah, tentu saja tidak dengan mudah diterima masyarakat. Pandemi virus Covid-19 di Indonesia memaksa aktivitas belajar mengajar tatap muka di sekolah dihentikan. Tidak ingin penularan Covid-19 semakin merajalela, pemerintah melalui Kementerian Pendidikan dan Kebudayaan memutuskan untuk memindahkan ruang belajar ke dunia maya. Sesuai dengan Surat Edaran Kemendikbud No. 15 Tahun

Jurnal Pendidikan IImu Sosial, Vol. 31, No.1, Juni 2021,

p-ISSN: 1412-3835; e-ISSN: 2541-4569 
2020, program belajar dari rumah tersebut dinamakan Pembelajaran Jarak Jauh (PJJ) (Kementerian Pendidikan dan Kebudayaan, 2020).

Pelaksanaan PJJ yang selama ini dilaksanakan banyak mengalami kendala, terutama pada permasalahan kedisiplinan dan pendidikan karakter yang kurang diimplementasikan (Handayani, 2021). Kurangnya pengawasan secara langsung dari guru, membuat murid kurang memperhatikan tugas-tugas yang menjadi kewajibannya. Demikian juga dengan respon murid terhadap guru ketika melakukan kegiatan pembelajaran, belum sesuai dengan harapan.

Pembelajaran Jarak Jauh (PJJ) di SMP Negeri 1 Banyumas, terutama pada mata pelajaran Ilmu Pengetahuan Sosial (IPS) juga mengalami kendala yang serupa. Berdasarkan observasi awal dari guru, selama tiga bulan pertama di semester gasal tahun 2020/2021, umumnya faktor kedisiplinan adalah masalah utama. Sekitar 10 dari 31 murid dalam satu kelas, kurang merespon guru ketika membuka pelajaran, mengerjakan tugas tidak tepat waktu dan bahkan tidak mengikuti pelajaran tanpa ijin. Langkah yang diambil guru yaitu dengan pola penerapan kedisiplinan berupa reward dan sanksi (Suyuthi \& Sun'an, 2018). Namun kenyataannya, hal tersebut belum menjadi suatu solusi untuk menerapkan disiplin positif pada murid. Bahkan menurut Wijaya (dalam Satria t.t.) hukuman tidak akan memberi efek positif apapun dan hanya memberi efek negatif jangka panjang sehingga akan merugikan anak.

Selama ini hukuman merupakan bentuk pembelajaran disiplin bagi murid, padahal hukuman mempunyai arti berbeda. Hukuman tidak lebih dari cara untuk mengarahkan sebuah perilaku agar sesuai dengan peraturan yang berlaku. Secara umum hukuman dalam hukum adalah sanksi fisik maupun psikis untuk kesalahan atau pelanggaran yang dilakukan yang berpengaruh untuk karakter peserta didik dan tidak bagus untuk psikologis anak (Rakhil, 2015). Disiplin dalam implikasi pembelajaran yaitu melatih seseorang untuk patuh terhadap peraturan atau perilaku jangka pendek maupun jangka panjang. Sementara hukuman bertujuan mengendalikan perilaku murid, disiplin dimaksudkan untuk mengembangkan perilaku murid tersebut dan mengajarkan kepercayaan diri dengn memfokuskan pada apa yang mampu dipelajari (Patricia, dkk, 2020).

Durrant (2010) mengemukakan bahwa disiplin positif adalah pendekatan pembelajaran yang membantu anak-anak berhasil, memberi mereka informasi yang mereka butuhkan dalam belajar, dan mendukung perkembangan mereka. Langkah pertama yang dalam menerapkan disiplin positif adalah mengembangkan visi bersama tentang apa yang ingin dicapai sekolah. Guru harus mampu memfasilitasi pembelajaran, berfokus pada kekuatan dan kelebihan murid, bukan hanya mencoba mengendalikan hal tersebut (Ramadania \& Aswadi, 2020).

Bentuk merdeka belajar dalam penerapan disiplin positif, salah satunya adalah dengan membangun kesepakatan kelas. Kesepakatan kelas berisi beberapa aturan untuk membantu guru dan murid bekerja bersama membentuk kegiatan belajar mengajar yang efektif (Sobri, Nursaptini, Widodo, \& Sutisna, 2019). Kesepakatan kelas tidak hanya berisi harapan guru terhadap murid, tapi juga harapan murid

Jurnal Pendidikan IImu Sosial, Vol. 31, No.1, Juni 2021,

p-ISSN: 1412-3835; e-ISSN: 2541-4569 
terhadap pengajar. Kesepakatan disusun dan dikembangkan bersama-sama antara guru dan murid. Dalam menyusun kesepakatan kelas, guru perlu mempertimbangkan hal yang penting dan hal yang bisa dikesampingkan. Hal ini sangat berbeda dengan bentuk tata tertib yang sebelumnya sudah ditentukan oleh guru atau pihak sekolah.

Penerapan disiplin positif di kelas, akan memberikan kontribusi pada penerapan budaya sekolah. Menurut Suharsaputra (2012), budaya sekolah adalah gambaran dari perilaku organisasi yang membedakan antara sekolah satu dengan lainnya, bagaimana semua pemangku kepentingan sekolah berperan dalam tugasnya tergantung pada keyakinan, nilai dan norma yang merupakan budaya sekolah tersebut. Hal ini sejalan dengan pendapat Komariah \& Triatna (2010: 102) yang menyatakan bahwa budaya sekolah yang efektif merupakan nilai-nilai, kepercayaan, dan tindakan sebagai hasil kesepakatan bersama yang melahirkan komitmen seluruh personel untuk melaksanakannya secara konsekuen dan konsisten. Budaya sekolah merupakan ciri khas sekolah yang dapat diidentifikasi melalui nilai yang menjadi pedoman, serta kebiasaan dan tindakan yang ditunjukkan oleh semua pemangku kepentingan yang merupakan sistem sekolah.

Berdasarkan pengalaman empiris dan kajian teoretis, terkait penerapan disiplin positif di sekolah, maka dirasa perlu untuk menerapkan disiplin positif pada pembelajaran IPS dengan membangun kesepakatan kelas, menerapkan dan bagaimana melakukan refleksi untuk menjaga konsistensi agar murid selalu berpedoman pada kesepakatan kelas yang telah dibangun. Tujuan penelitian ini adalah mendeskripsikan disiplin positif dalam pembelajaran jarak jauh pada mata pelajaran IPS di SMP Negeri 1 Banyumas.

\section{METODE PENELITIAN}

Penelitian ini menggunakan pendekatan kualitatif. Penelitian kualitatif dilakukan untuk mengkonstruksi pengetahuan yang dilakukan melalui metode dengan meneliti suatu gambaran peristiwa sosial dan manusia. Pada intinya, penelitian kualitatif lebih kepada kegiatan mengamati orang dalam berinteraksi di lingkungannya. Peneliti harus berusaha memahami bahasa dan pendapat mereka tentang lingkungan sekitarnya serta menggali pendapat dan pengalaman mereka untuk mendapat informasi atau data yang dibutuhkan (Iskandar, 2009: 51-55).

Teknik pengumpulan data menggunakan metode observasi, angket dan dokumentasi. Metode observasi dapat dilakukan dengan melengkapi format atau blangko pengamatan sebagai instrument dengan hasil yang efektif (Arikunto, 2009: 226). Sebagai metode ilmiah observasi (pengamatan) diartikan sebagai pengamatan pencatatan sistematis dari fenomena-fenomena yang diselidiki. Dalam penelitian ini metode observasi digunakan untuk mengumpulkan data antara lain: mengamati keadaan murid yang sedang belajar PJJ, observasi dilakukan secara nonpartisipan, dimana peneliti berperan hanya sebagai pengamat fenomena yang diteliti. Pengamatan dilakukan secara langsung melalui kegiatan PJJ menggunakan Google

Jurnal Pendidikan IImu Sosial, Vol. 31, No.1, Juni 2021,

p-ISSN: 1412-3835; e-ISSN: 2541-4569 
Meet untuk mendapatkan gambaran yang utuh terkait fokus penelitian. Hasil pengamatan disusun dalam catatan lapangan. Catatan lapangan ini berisi tentang peristiwa yang selalu terjadi, atau secara periodik, adanya interaksi dan interpretasinya.

Selanjutnya, angket diberikan melalui Google Form yang dibagikan kepada murid. Hasil angket digunakan untuk mengambil data respon murid terhadap penerapan kedisiplinan melalui kesepakatan kelas. Metode ketiga yaitu melalui dokumentasi, dalam penelitian ini, dokumen yang digunakan berupa hasil tugas murid, daftar nilai dan daftar hadir serta hasil respon murid dalam Google Classroom.

Dalam penelitian ini analisis data dilakukan secara berurutan dari awal sampai akhir, baik di lapangan maupun tidak dengan mengggunakan teknik seperti yang disampaikan oleh Miles, Huberman, \& Saldana (2014), yaitu pertama, mereduksi data, yaitu dengan proses abstraksi data hasil catatan lapangan dan hasil observasi serta wawancara dan pengkajian dokumen. Reduksi data yaitu bentuk analisis data dengan teknik penajaman, menyimpulkan hal-hal penting, menggolongkan, mengarahkan, dan membuang yang tidak diperlukan agar sistematis sehingga dapat diambil kesimpulan yang bermakna. Dengan demikian, semua data yang diperoleh melalui observasi, wawancara dan dokumen dikumpulkan, diseleksi, dan dikategorikan lalu disimpulkan dengan tidak menghilangkan nilai data itu sendiri.

Berikutnya adalah penyajian data yaitu informasi yang memberi peluang adanya pengambilan kesimpulan dalam suatu tindakan. Proses penyajian data ini menggambarkan secara menyeluruh dari data-data yang diperoleh agar mudah dibaca dan dipahami. Penelitian kualitatif umumnya dalam menyajikan data menggunakan teks yang bersifat naratif (Sugiyono, 2011: 341). Data dapat menggambarkan bagaimana penerapan disiplin positif dalam pembelajaran jarak jauh pada mata pelajaran IPS di SMP Negeri 1 Banyumas.

Proses terakhir yaitu pengambilan kesimpulan dan verifikasi data yang sudah diatur sedemikian rupa dengan susunan sistematis, kemudian disimpulkan sehingga makna dari data dapat simpulkan. Kegiatan mereduksi data, dan penyimpulan terhadap hasil penelitian yang dilakukan memberikan kemudahan pembaca dalam memahami proses dan hasil penelitian tentang penerapan budaya positif murid dalam pembelajaran jarak jauh di SMP Negeri 1 Banyumas.

\section{HASIL PENELITIAN DAN PEMBAHASAN}

Pendidikan adalah sesuatu yang direncanakan, dalam proses membimbing dan memberikan pelajaran bagi murid agar dapat berkembang dan tumbuh menjadi manusia mandiri, bertanggung jawab, kreatif, memiliki ilmu yang luas dan berakhlak mulia (Nofijantie, 2012: 294). Hal ini menunjukkan bahwa tujuan pendidikan berlandaskan karakter merupakan hal yang sangat penting. Menurut Center for Curriculum Redesign (2015), tujuan pendidikan karakter secara luas yaitu 1) membangun landasan pembelajaran seumur hidup; 2) mendukung kerjasama

Jurnal Pendidikan IImu Sosial, Vol. 31, No.1, Juni 2021,

p-ISSN: 1412-3835; e-ISSN: 2541-4569 
yang baik dalam komunitas maupun tempat kerja; serta 3) mengembangkan nilainilai individu agar mampu berkontribusi di kehidupan yang lebih luas.

Membangun karakteristik murid bukanlah hal yang mudah, namun sebagai pendidik juga diberi tugas untuk dapat membentuk calon-calon penerus bangsa yang memiliki karakter jujur, berkeadilan, bertanggung jawab, peduli dan saling menghormati. Sebagai seorang pendidik, guru harus dapat mengembangkan budaya positif di sekolah, dimulai dari membekali diri dengan melatih komunikasi. Komunikasi yang baik, harus berlangsung dua arah, agar mampu menjadi jembatan yang baik antara guru dan murid. Guru dan murid sama- sama diberikan ruang bertumbuh dalam diskusi, terutama ketika menerapkan aturan, mendisiplinkan dan membangun karakter (Patricia, dkk, 2020).

Proses kegiatan pembelajaran di SMP Negeri 1 Banyumas pada masa pandemi Covid-19 harus mengikuti anjuran dari pemerintah yaitu melalui Pembelajaran Jarak Jauh (PJJ) yang dilaksanakan sejak Maret 2020. PJJ yang dilakukan sudah terorganisasi dengan baik yaitu dengan menggunakan media Google Classroom, dimana semua guru dan murid memiliki akun sekolah, sehingga memudahkan untuk mengakses semua hal yang berkaitan dengan PJJ. Meskipun media sudah terorganisasi dengan baik, namun dalam pelaksanaannya, belum mampu berjalan secara maksimal. Hal ini terutama berkaitan dengan masalah kedisiplinan murid di dalam mengumpulkan tugas, keikutsertaan dalam PJJ, dan juga merespon informasi yang diberikan guru, baik melalui WhatsApp Group maupun Google Classroom. Penelitian ini dilaksanakan melalui tiga tahap, yaitu observasi awal, pelaksanaan dan pelaporan. Observasi awal dilakukan selama tiga bulan dengan mengamati proses PJJ yang sedang berlangsung dan mengetahui permasalahannya. Berikut ini disajikan kondisi awal kedisiplinan murid selama mengikuti PJJ.

Tabel 1.

Kedisiplinan Murid Kondisi Awal

\begin{tabular}{ccccc}
\hline No & Kelas & Jml Murid & $\begin{array}{c}\text { Pengumpulan Tugas } \\
\text { Tepat Waktu }\end{array}$ & Presensi PJJ \\
\hline 1 & $9 \mathrm{~A}$ & 31 & 22 & 23 \\
2 & $9 \mathrm{~B}$ & 29 & 20 & 22 \\
3 & $9 \mathrm{C}$ & 31 & 23 & 22 \\
4 & $9 \mathrm{D}$ & 31 & 22 & 23 \\
5 & $9 \mathrm{E}$ & 31 & 22 & 25 \\
6 & $9 \mathrm{~F}$ & 31 & 20 & 23 \\
\hline Jumlah & 184 & 129 & 138 \\
\hline \multicolumn{2}{c}{$\%$ rerata } & & $70 \%$ & $75 \%$ \\
\hline \multicolumn{2}{l}{ Kualifikasi } & Cukup Baik & Baik \\
\hline
\end{tabular}

Berdasarkan data pada Tabel 1, selama tiga bulan terakhir pada semester gasal tahun 2020/2021, rata-rata tingkat kehadiran murid dalam PJJ sebesar 75\%. Sedangkan kedisiplinan murid dalam pengumpulan tugas atau merespon guru rata-

Jurnal Pendidikan IImu Sosial, Vol. 31, No.1, Juni 2021,

p-ISSN: 1412-3835; e-ISSN: 2541-4569 
rata 70\%. Berbagai kendala dalam PJJ tersebut, telah banyak diupayakan oleh guru maupun pihak sekolah, namun hasilnya belum sesuai dengan harapan.

Berkaitan dengan masalah ini, solusi yang telah diterapkan yaitu dengan adanya aturan dan tata tertib sekolah, serta sanksi yang diterapkan. Bentuk sanksi atau hukuman ternyata tidak menjadi sebuah solusi dalam menerapkan kedisiplinan di sekolah. Guru seringkali memandang bahwa hukuman adalah bentuk yang sama dengan proses pendisiplinan dan memberikan hukuman sebagai langkah dalam proses disiplin murid.

Padahal menurut Wijaya (dalam Satria t.t.), hukuman tidak akan memberi efek positif apapun dan hanya memberi efek negatif jangka panjang sehingga akan merugikan anak. Demikian juga pendapat Centre for Justice and Crime Prevention and the Department of Basic Education (2012) yang menyatakan bahwa hukuman seringkali dilakukan dengan kekerasan fisik, verbal dan agresif pada murid, sehingga hal ini hanya akan memaksa murid untuk patuh, bukan melalui proses memahami mana situasi benar dan salah.

Berdasarkan pengalaman penerapan sanksi atau hukuman tersebut, maka solusi kedisiplinan murid selama PJJ dapat dilakukan melalui penerapan disiplin positif. Disiplin positif adalah pendekatan pembelajaran yang membantu anak-anak berhasil, memberi mereka informasi yang dibutuhkan dalam belajar, dan mendukung perkembangan mereka (Durrant, 2010). Hal ini sejalan dengan pendapat Nelsen, dkk (dalam Hidayat, Danarti, \& Darwati, 2016: 472), disiplin positif adalah "program yang dirancang untuk mengajarkan anak menjadi bertanggung jawab serta hormat pada anggota dari komunitas mereka".

Lebih lanjut, Nelsen mengemukakan bahwa anak dididik untuk memiliki keterampilan sosial mereka, untuk menjadi pribadi yang memiliki rasa empati, menghormati dan menghargai sesamanya dan terutama mampu menyelesaikan setiap permasalahan dengan tanpa menyakiti orang lain. Hal yang sama disampaikan oleh Patricia, dkk (2020), disiplin positif merupakan pendekatan yang dirancang untuk mengembangkan murid menjadi pribadi yang bertanggung jawab, penuh hormat, dan kritis.

Tahap pelaksanaan penelitian dilakukan selama satu bulan, pada kelas 9A sampai 9F pada mata pelajaran IPS. Adapun langkah-langkah disiplin positif pada pembelajaran IPS di SMP Negeri 1 Banyumas, diawali dengan membangun kesepakatan kelas, penerapan dan refleksi agar murid selalu berpedoman pada kesepakatan kelas yang telah dibangun. Kesepakatan kelas adalah aturan untuk membantu guru dan murid bekerja bersama membentuk kegiatan belajar mengajar yang efektif (Patricia, dkk, 2020).

Kesepakatan kelas tidak hanya berisi harapan guru terhadap murid, tapi juga harapan murid terhadap pengajar. Kesepakatan kelas disusun dan dikembangkan bersama antara guru dan murid. Agar murid tidak mengalami kesulitan dalam mengingat banyak informasi, maka kesepakatan kelas disusun 4-8 aturan untuk setiap kelas. Ini merupakan salah satu bentuk merdeka belajar, yang saat ini sedang

Jurnal Pendidikan IImu Sosial, Vol. 31, No.1, Juni 2021,

p-ISSN: 1412-3835; e-ISSN: 2541-4569 
dikembangkan. Tata tertib bukan lagi ditentukan oleh guru atau sekolah, namun melalui kesepakatan yang dibangun antara guru dan murid.

\section{Penentuan Kesepakatan Kelas}

Implementasi penentuan kesepakatan kelas pada pembelajaran IPS di masa PJJ yang penulis dan murid lakukan yaitu, 1) membuat formulir secara online untuk menggali keinginan murid tentang kelas impian mereka, dan menuliskan kesepakatan apa yang perlu dibangun; 2) merekap dan menyimpulkan pendapat murid melalui respon dari formulir yang dibagikan; 3) mengklarifikasi hasil simpulan kesepakatan kelas kepada semua murid melalui grup chat dan Google Classroom, untuk dikomentari murid agar terjadi kesepakatan; 4) menetapkan ketentuan kelas yang telah disepakati dengan menjadikan wallpaper di Google Classroom dan grup chat agar selalu terlihat oleh murid sehingga memudahkan murid untuk mengingat dan melaksanakannya.

Adapun hasil respon murid pada saat penentuan kesepakatan kelas dapat dilihat dalam Tabel 2 berikut.

Tabel 2.

\begin{tabular}{cccc}
\multicolumn{3}{c}{ Respon Murid dalam Membangun Kesepakatan Kelas } \\
\hline No & Kelas & Jml Murid & Jml Respon Murid \\
& & & 29 \\
1 & $9 \mathrm{~A}$ & 31 & 26 \\
2 & $9 \mathrm{~B}$ & 29 & 26 \\
3 & $9 \mathrm{C}$ & 31 & 28 \\
4 & $9 \mathrm{D}$ & 31 & 25 \\
5 & $9 \mathrm{E}$ & 31 & 26 \\
6 & $9 \mathrm{~F}$ & 31 & 160 \\
\hline Jumlah & 184 & $86,95 \%$ \\
\hline \% rerata & & Sangat Baik \\
\hline \multicolumn{3}{c}{ Kualifikasi } \\
\hline
\end{tabular}

Berdasarkan hasil pada Tabel 2, respon murid terhadap formulir yang dibagikan guru secara online melalui Google Classroom ditanggapi positif oleh murid sebanyak 86,95\%. Jika dikaitkan dengan rentang persentase, maka respon murid dalam berkontribusi membangun kesepakatan kelas, dapat dikategorikan sangat baik. Rentang persentase tersebut yaitu >= 85\% sangat baik, 70\%- 85\% baik, 55\% - 70\% cukup, 40\%- 55\% kurang dan di bawah 40\% sangat kurang. Hasil respon murid tentang poin-poin kesepakatan kelas selanjutnya direkap oleh guru, kemudian diambil kesimpulan serta dikonfirmasikan kembali pada murid melalui Google Classroom untuk mendapatkan masukan dan persetujuan bersama antara guru dan murid dalam proses pelaksanaan pembelajaran jarak jauh.

Hasil kesimpulan respon kesepakatan kelas tersebut, yaitu merespon apa yang diinfokan oleh guru, mengumpulkan tugas tepat waktu, presensi tepat waktu, ijin jika berhalangan hadir, jika terkendala jaringan diberi perpanjangan waktu untuk mengumpulkan tugas dengan memberikan konfirmasi kepada guru, pengurus kelas

Jurnal Pendidikan IImu Sosial, Vol. 31, No.1, Juni 2021,

p-ISSN: 1412-3835; e-ISSN: 2541-4569 
selalu mengingatkan teman temannya untuk mengisi presensi dan mengikuti pelajaran sampai selesai. Hasil kesepakatan dijadikan wallpaper pada Google Classroom agar setiap murid selalu mengingat kesepakatan yang telah dibangun bersama agar kedisiplinan murid dapat ditingkatkan. Kesepakatan kelas yang telah disusun selanjutnya diterapkan di dalam proses PJJ dengan guru sebagai pendidik.

\section{Penerapan Disiplin Positif melalui Kesepakatan Kelas}

Penerapan kesepakatan kelas merupakan bentuk disiplin positif, meski hal ini tidak mudah untuk dilakukan. Apalagi ketika kita berhadapan dengan berbagai jenis murid yang memiliki sifat uniknya masing-masing. Kesepakatan kelas yang efektif dapat membantu dalam pembentukan disiplin positif di kelas. Hal ini juga dapat membantu proses belajar mengajar yang lebih mudah dan tidak menekan. Pada proses penerapannya, guru harus betul-betul memantau dan selalu mengingatkan murid tentang kesepakatan tersebut. Tidak jarang, murid yang tidak melaksanakan kesepakatan dengan baik. Untuk itu, guru harus mempunyai berbagai strategi untuk mengingatkan murid dengan komunikasi yang baik.

Kesepakatan kelas sebagai wujud disiplin positif pada dasarnya bertujuan untuk membangun kekuatan murid daripada mengkritik kelemahan mereka dan menggunakan penguatan positif untuk mempromosikan perilaku yang baik. Pada saat ada murid yang tidak melaksanakan kesepakatan kelas, maka guru bukan memberikan kosekuensi berupa hukuman, namun konsekuensi alami bagi para pelanggarnya, misalnya, merasa tidak nyaman sediri, malu, dan sebagainya. Sebelum menentukan konsekuensi, guru juga harus melihat situasinya apakah pelanggaran tersebut memerlukan konsekunsi tambahan yang lebih berat. Namun pada dasarnya, bukan bersifat hukuman fisik atau tidak menjaga harga diri murid. Hukuman tidak akan memberikan pengalaman belajar yang baik.

Menurut Patricia, dkk (2020), meskipun penerapan disiplin positif dalam kesepakatan kelas tidak menggunakan kosekuensi hukuman, namun disiplin positif bukanlah membiarkan peserta didik melakukan apapun yang mereka inginkan dan tidak memiliki aturan, batasan atau harapan. Namun, dengan cara adanya penguatan harapan, aturan, dan batasan serta membangun hubungan yang saling menghormati dengan murid. Guru juga mengajarkan sopan santun, tanpa kekerasan, empati, harga diri, dan rasa hormat untuk orang lain dan hak-hak mereka.

Kunci keberhasilan dalam pengembangan disiplin positif yaitu menciptakan kelas yang berpusat pada murid dan melibatkan serta bekerja sama dengan orang tua dalam penerapan disiplin positif. Oleh karena itu, dalam penerapan kesepakatan kelas, guru tidak pernah bosan mengingatkan murid melalui grup chat serta Google Classroom agar murid selalu memperhatikan kesepakatan yang telah ditentukan. Untuk murid yang berkali-kali melanggar kesepakatan kelas, guru berkomunikasi secara pribadi melalui chat dengan bahasa yang tidak menyudutkan murid. Guru

Jurnal Pendidikan IImu Sosial, Vol. 31, No.1, Juni 2021,

p-ISSN: 1412-3835; e-ISSN: 2541-4569 


\section{JPIS

menggali apa yang menjadi kendala dan membicarakan solusi tersebut dengan murid dan orang tua.

Ketika seorang murid telah melakukan kesalahan, tantangan pertama adalah untuk memahami alasan perilaku murid, lalu merefleksikan apakah ada konsekunsi dari perilaku tersebut. Seringkali perilaku buruk dihasilkan dari faktor-faktor di luar kendali murid, seperti masalah di rumah. Hal ini harus segera dikomunikasikan dengan orang tua untuk mencari solusi. Hal lain misalnya, murid tidak tepat waktu dalam mengikuti PJJ karena mereka tidak percaya ketepatan waktu itu penting. Keyakinan ini yang dikoreksi guru melalui respon disipliner, dan menunjukkan bahwa keyakinan murid itu bisa diperbaiki dengan komunikasi yang santun.

Pengaruh penerapan disiplin positif yang dirasakan oleh penulis, berdasarkan pada hasil penulisan yang dilakukan kepada murid, tedapat beberapa pengaruh yang terjadi akibat penerapan disiplin positif di sekolah. Pertama, pengaruh langsung yang terjadi kepada guru, yaitu a) guru tidak lagi menghukum murid yang salah dengan hukuman fisik atau emosional; b) penggunaan hukum yang dialihkan kepada kesepakatan kelas atau konsekuensi logis, yang telah dibuat oleh guru dengan melibatkan murid dalam proses penentuan konsekuensi logis sebagai sarana pengganti hukuman contoh apabila murid terlambat mengumpulkan tugas maka konsekuensinya murid akan diberi tambahan tugas dan waktu; c) guru mampu menghubungkan antara tindakan yang diberikan terhadap prilaku murid melalui kesepakatann kelas dan konsekuensi logis yang dibuat, contohnya apabila ada murid yang tidak mengikuti PJJ tanpa ijin, maka murid harus membuat rangkuman materi sesuai dengan materi yang diajarkan saat itu; d) guru lebih mampu menggunakan kata-kata yang baik (positif) serta santun dalam memberikan atau menyampaikan sesuatu larangan. Misalnya, mengganti kata "jangan" atau "tidak boleh" dengan "akan lebih baik", hal ini memotivasi guru untuk tidak selalu menyalahkan murid dalam perilaku yang dilakukan; e) guru mampu memahami bahwa perilaku menyimpang murid tidak semata-mata karena kenakalan, tetapi melainkan ada faktor lain, hal ini menjadikan guru lebih arif dan bijak dalam menyikapi problematika anak.

Adapun pengaruh penerapan kesepakatan bagi murid berdasarkan hasil pengamatan guru melalui kegiatan PJJ yaitu; a) murid lebih mampu menghargai guru sebagai pendidik, dibuktikan melalui respon positif yang diberikan saat PJJ; b) murid lebih mampu diajak bertukar pikiran dan berdiskusi, untuk berkontribusi langsung pada saat penyusunan kesepakatan kelas atau penyusunan konsekuensi logis; c) murid menyadari akan kesepakan kelas dan konsekuensi logis yang dibuat bersama guru, dengan contoh murid mampu menegur murid lain yang belum berpartisipasi aktif dan saling mengingatkan; d) murid menjadi lebih aktif dan terbuka akan hal-hal yang dialaminya baik di sekolah maupun di rumah; e) murid lebih sopan dalam berkomunikasi melalui media sosial. Terkait dengan kedisiplinan murid dalam presensi dan penugasan, juga mengalami kenaikan yang cukup

Jurnal Pendidikan IImu Sosial, Vol. 31, No.1, Juni 2021,

p-ISSN: 1412-3835; e-ISSN: 2541-4569 
signifikan. Melalui dokumen nilai tugas dan respon presensi Google Form pada Classroom.

Tabel 3

Kedisiplinan Murid Kondisi Akhir

\begin{tabular}{ccccc}
\hline No & Kelas & Jml Murid & $\begin{array}{c}\text { Pengumpulan Tugas } \\
\text { Tepat Waktu }\end{array}$ & Presensi PJJ \\
\hline 1 & $9 \mathrm{~A}$ & 31 & 26 & 26 \\
2 & $9 \mathrm{~B}$ & 29 & 24 & 27 \\
3 & $9 \mathrm{C}$ & 31 & 25 & 28 \\
4 & $9 \mathrm{D}$ & 31 & 27 & 28 \\
5 & $9 \mathrm{E}$ & 31 & 28 & 28 \\
6 & $9 \mathrm{~F}$ & 31 & 28 & 28 \\
\hline \multicolumn{2}{c}{ Jumlah } & 184 & 158 & 165 \\
\hline \multicolumn{2}{c}{$\%$ rerata } & & $86 \%$ & Sangat Baik \\
\hline \multicolumn{2}{l}{ Kualifikasi } & & Sangat Baik & \\
\hline
\end{tabular}

Berdasarkan hasil pada Tabel 3 tersebut dapat dilihat bahwa penerapan disiplin positif melalui kesepakatan kelas dapat meningkatkan kedisiplinan murid dalam mengikuti PJJ, hasil pengamatan sebesar $90 \%$ presensi tepat waktu, dan melaksanakan tugas tepat waktu sebesar $86 \%$ atau pada kualifikasi sangat baik.

\section{Refleksi Penerapan Kesepakatan Kelas}

Kesepakatan kelas sebagai wujud disiplin positif, bukanlah suatu hal yang tidak bisa diperbarui. Namun, seiring dengan tahap perkembangan murid dan perubahan situasi, diperlukan evaluasi atas kesepakatan. Karena adanya kondisi yang berbeda, adanya evaluasi atas kesepakatan pun secara berkala mutlak harus dilakukan. Seperti halnya kesepakatan dalam pembelajaran IPS ini, guru dan murid menambah poin kesepakatan pada bulan kedua dikarenakan banyak murid yang tidak merespon pertanyaan atau materi guru, namun hanya mengerjakan tugas saja. Oleh karena itu, pada kesepakatan kelas ada penambahan kesepakatan, yaitu "murid wajib berpartisipasi aktif dalam diskusi". Hasil angket dengan murid melalui google form yang dibagikan guru terkait penerapan disiplin positif juga mendapatkan respon yang sangat baik, yaitu sebesar 96,73\% murid menanggapi positif penerapan disiplin positif melalui kesepakatan kelas.

Tabel 4

Respon Kedisiplinan Murid Kondisi Akhir

\begin{tabular}{clccc}
\hline \multirow{2}{*}{ No } & \multicolumn{1}{c}{ Rumusan Instrumen } & Ya & \multicolumn{2}{c}{ Respon Murid } \\
& \multicolumn{1}{c}{ Tidak } & Tdk Merespon \\
\hline 1 & $\begin{array}{l}\text { Apakah kesepakatan kelas membuatmu } \\
\text { nyaman dalam PJJ IPS }\end{array}$ & 175 & - & 5 \\
2 & $\begin{array}{l}\text { Apakah kesepakatan kelas membuatmu } \\
\text { lebih disiplin? }\end{array}$ & 174 & - & 5 \\
3 & $\begin{array}{l}\text { Apakah dalam menjalankan kesepakatan } \\
\text { kelas, kamu tidak terpaksa? }\end{array}$ & 179 & - & 5 \\
\hline
\end{tabular}

Jurnal Pendidikan IImu Sosial, Vol. 31, No.1, Juni 2021, 


\begin{tabular}{|c|c|c|c|c|}
\hline \multirow{2}{*}{ No } & \multirow{2}{*}{ Rumusan Instrumen } & \multicolumn{3}{|c|}{ Respon Murid } \\
\hline & & Ya & Tidak & Tdk Merespon \\
\hline 4 & Apakah guru melayani murid dengan baik? & 179 & - & 5 \\
\hline 5 & Apakah guru memberikan hukuman? & 179 & - & 5 \\
\hline 6 & $\begin{array}{l}\text { Apakah guru mendengarkan keluhan } \\
\text { murid? }\end{array}$ & 179 & - & 5 \\
\hline 7 & $\begin{array}{l}\text { Apakah guru berkata sopan dalam } \\
\text { berkomunikasi? }\end{array}$ & 179 & - & 5 \\
\hline 8 & $\begin{array}{l}\text { Apakah guru menghadapi murid dengan } \\
\text { bijaksana? }\end{array}$ & 179 & - & 5 \\
\hline 9 & $\begin{array}{l}\text { Apakah guru selalu mengajarkan } \\
\text { kedisiplinan? }\end{array}$ & 179 & - & \\
\hline 10 & Apakah guru memaafkan kesalahan murid? & 179 & - & \\
\hline \multicolumn{2}{|c|}{ Rerata } & 178 & 5 & 5 \\
\hline \multicolumn{2}{|c|}{ Persentase (Jml Murid 184) } & $96,73 \%$ & $2,71 \%$ & $2,71 \%$ \\
\hline \multicolumn{2}{|c|}{ Kategori } & \multicolumn{3}{|c|}{ Sangat Baik } \\
\hline
\end{tabular}

Hasil jawaban angket murid pada Tabel 4, murid merespon positif penerapan disiplin murid melalui kesepakatan kelas, dan secara konsisten melaksanakan apa yang telah menjadi kesepakatan dengan kesadaran yang dibangun melalui pembiasaan pada proses PJJ IPS di SMP Negeri 1 Banyumas. Bagi murid yang melanggar kesepakatan kelas, guru bukan memberikan hukuman sebagai konsekuensinya, namun lebih kepada konsekuensi alamiah yang dirasakan sendiri oleh murid. Konsekuensi tambahan diberikan kepada murid yang melakukan pelanggaran berulang, berupa penambahan penugasan, bukan berupa hukuman yang akan menurunkan harga diri murid.

Hasil penelitian ini merupakan pengembangan dari penelitian sebelumnya, yaitu hasil penelitian terdahulu berkaitan dengan budaya positif di sekolah yaitu penulisan yang dilakukan oleh Johannes (2017), bahwa pengelolaan kelas mampu meningkatkan sikap positif disiplin murid. Sejalan dengan hal tersebut, Mulyani, Sumantri, \& Budimansyah (2020) menjelaskan bahwa internalisasi nilai-nilai karakter melalui penerapan disiplin positif adalah salah satu cara yang dilakukan dengan membangun budaya sekolah yang positif dan kondusif.

Pengembangan disiplin positif memerlukan hubungan positif yang didasari oleh pemahaman dan empati maka murid akan mempercayai guru serta menghargai kepemimpinan guru. Pada saat PJJ, jika murid selalu merespon dengan baik hal positif dalam kedisiplinan secara konsisten, dan mampu berkomunikasi dengan baik dengan guru, maka tingkat kejadian pelanggaran akan menurun (Arifin, Hartati, Silaen, \& Yusoh, 2020). Sebaliknya, jika hubungan guru dengan murid tidak terjalin dengan baik, maka tingkat pelanggaran akan terus meningkat. Sejalan dengan hal tersebut Hortensi (2020) mengemukakan pentingnya terjalin komunikasi yang baik antara siswa dengan guru dalam upaya meningkatkan kedispilinan di dalam kelas.

Oleh karena itu dapat disimpulkan bahwa guru yang baik adalah guru yang dapat menjadi panutan, guru yang peduli serta menginginkan untuk membangun

Jurnal Pendidikan IImu Sosial, Vol. 31, No.1, Juni 2021,

p-ISSN: 1412-3835; e-ISSN: 2541-4569 
hubungan yang akrab dan menyenangkan dengan murid-muridnya. Agar penerapan disiplin positif dapat mewujudkan visi dan misi sekolah, maka perlu dikembangkan penciptaan lingkungan belajar yang ramah murid, pendidik, dan orang tua merasa dihargai dan didukung, serta murid mempunyai ruang untuk mengekspresian pandangan mereka (Patricia, dkk, 2020).

\section{KESIMPULAN}

Penerapan disiplin positif murid dalam PJJ pada mata pelajaran IPS di SMP Negeri 1 Banyumas yaitu diawali dengan penyusunan kesepakatan kelas yang dilakukan oleh guru dan murid. Penyusunan kesepakatan kelas mendapat respon yang baik dari murid, sebanyak 86,95\% ikut berkontribusi memberikan masukan untuk disepakati. Hasil penerapan kesepakatan kelas berpengaruh langsung kepada guru dan murid. Secara umum penanaman disiplin positif ini memiliki pengaruh yang positif. Berdasarkan hasil penelitian, kedisiplinan murid juga mengalami kenaikan yang cukup signifikan, dilihat dari dokumen nilai tugas dan respon presensi di google form melalui classroom sebesar 86\% mengumpulan tugas tepat waktu dan 90\% presensi tepat waktu. Hasil angket dengan murid melalui Google Form yang dibagikan guru terkait penerapan disiplin positif juga mendapatkan respon yang sangat baik, yaitu sebesar 96,73 \% murid menanggapi positif. Meskipun penerapan disiplin positif ini mendapatkan respon yang sangat baik, namun secara berkala perlu ditinjau ulang kesepakatan kelas untuk disesuaikan lagi dengan kondisi saat itu dan dilakukan refleksi untuk peningkatan kedisiplinan. Maka dari itu, peneliti selanjutnya diharapkan dapat mengembangkan penerapan disiplin positif dalam PJJ menggunakan model atau media lain yang lebih inovatif. Upaya menjaga konsistensi penerapan kesepakatan kelas, hendaknya dapat diupayakan dengan menerapkan metode lain yang lebih efektif.

\section{DAFTAR PUSTAKA}

Arifin, M., Hartati, L., Silaen, V.A.F.R., \& Yusoh, M.A. 2020. Manajemen Pembelajaran Pendidikan Jarak Jauh untuk Milenial. Sukabumi: Haura Publishing.

Arikunto, S. 2009. Manajemen Penelitian. Jakarta: Rineka Cipta.

Durrant, J.E. 2010. Positive Discipline in Everyday Teaching: A guide for Educators. Sweden: Save the Children.

Handayani, T. 2021. Meningkatkan Hasil Belajar Siswa Selama Pandemi Dengan Pendidikan Karakter di Lingkungan Keluarga. RADIANT: Journal of Applied, Social, and Education Studies. 2(1), 41-50. https://doi.org/10.52187/rdt.v2i1.37.

Jurnal Pendidikan IImu Sosial, Vol. 31, No.1, Juni 2021, 
Hidayat, N., Danarti, \& Darwati, S. 2016. Disiplin Positif: Membentuk Karakter Tanpa Hukuman. Prosiding Seminar Nasional Pendidikan Berkemajuan dan Menggembirakan (The Progressive \& Fun Education Seminar). 471-477.

Hortensi, G. 2020. Penerapan Bimbingan Kelompok Dengan Teknik Konseling Individual Untuk Meningkatkan Disiplin Belajar Siswa SMK Negeri 5 Mataram. International Journal of Educational Development. 1(2), 159-169. https://doi.org/10.5281/zenodo.4003791.

Iskandar. 2009. Metodologi Penelitian Pendidikan dan Sosial. Jakarta: Gaung Persada Press.

Johannes, N. 2017. Peningkatan Sikap Positif Disiplin Melalui Pengelolaan Kelas Bagi Siswa SD Negeri 41 Ambon. PEDAGOGIKA: Jurnal Pedagogika dan Dinamika Pendidikan). 6(1), 45-47, https://doi.org/10.30598.

Kementerian Pendidikan dan Kebudayaan. 2020. Surat Edaran Nomor 15 Tahun 2020 tentang Pedoman Penyelenggaraan Belajar dari Rumah dalam Masa Darurat Penyebaran Corona Virus Disease (COVID-19). https://bersamahadapikorona.kemdikbud.go.id/wpcontent/uploads/2020/05/SE-Sesjen-Nomor-15-Tahun-2020-2.pdf.

Komariah, A. \& Triatna C. 2010. Visionary Leardership Menuju Sekolah Efektif. Jakarta: PT. Bumi Aksara.

Miles, M.B., Huberman, A.M., \& Saldana, J. 2014. Qualitative Data Analysis: A Methods Sourcebook. California: Sage Publications, Inc.

Mulyani, R., Sumantri, E., \& Budimansyah, D. 2020. The Application of Positive Discipline in Realizing Non-Violence Education in Child-Friendly Schools. Jurnal Civicus. 20(1), 40-50.

Nofijantie, L. 2012. Peran Lembaga Pendidikan Formal Sebagai Modal Utama Membangun Karakter Siswa. Skripsi. http://digilib.uinsby.ac.id/7494/.

Patricia, dkk. 2020. Modul Paradigma dan Visi Guru Penggerak. Jakarta: Kementerian Pendidikan dan Kebudayaan.

Rakhil, F. 2015. Urgensi Reward dan Punishment Dalam Pendidikan Anak Perspektif Psikologi Perkembangan. Jurnal Pikir: Jurnal Studi Pendidikan Dan Hukum Islam, 1(1), 31-47. Retrieved from http://ejournal.staidakrempyang.ac.id/index.php/pikir/article/view/95.

Jurnal Pendidikan IImu Sosial, Vol. 31, No.1, Juni 2021,

p-ISSN: 1412-3835; e-ISSN: 2541-4569 
Ramadania, F., \& Aswadi. D. 2020. Blended Learning dalam Merdeka Belajar Teks Eksposisi. Stilistika: Jurnal Bahasa, Sastra, dan Pengajarannya. 5(1), pp. 10-21 https://doi.org/10.33654/sti.v5i1.1014.

Satria, Rizky. t.t. Disiplin Positif: Membangun Nilai Kedisiplinan Tanpa Kekerasan Keselamatan Keluarga. Diakses $15 \quad$ Januari 2021. https://www.keselamatankeluarga.com/disiplin-positif-membangun-nilaikedisiplinan-tanpa-kekerasan/.

Sobri, M., Nursaptini, N., Widodo, A., \& Sutisna, D. 2019. Pembentukan Karakter Disiplin Siswa Melalui Kultur Sekolah. 6 (1), 61-71, https://doi.org/10.21831/hsjpi.v6i1.26912.

Sugiyono. 2011. Metode Penelitian Kuntitatif, Kualitatif dan R\&D. Bandung: Alfabeta.

Suharsaputra, U. 2012. Metode Penelitian: Kuantitatif, Kualitatif, dan Tindakan. Bandung: PT. Refika Aditama.

Suyuthi, A., \& Sun'an, A. 2018. Implementasi Reward dan Punishment Dalam Meningkatkan Kedisiplinan Belajar Siswa di MTS Roudlotul Muta'alimin Moropelang Babat Lamongan. Akademika. 12(2), 155-168. https://doi.org/10.30736/adk.v12i02.175. 